Pacific Journal of Mathematic 


\section{ON A THEOREM BY HOFFMAN AND RAMSAY}

\section{Stelios Negrepontis}

Hoffman and Ramsay recently constructed, using the continuum hypothesis, a proper subalgebra of the algebra $C(\beta N)$ of all complex-valued continuous functions on $\beta N$ which is uniformly closed and separates points of $\beta N$. (This example settles in the negative a conjecture by Badé and Curtis). The purpose of this note is to indicate that this result does not need the continuum hypothesis.

Their construction, in [3], naturally falls into two parts, the first of which is devoted to the proof that the space $X$ of maximal ideals of the algebra $L^{\infty}$ of all essentially bounded measurable complex-valued functions on the unit circle is homeomorphic to a subset of $\beta N-N$. It is in this part that they are forced to use the continuum hypothesis.

1. We have a simple proof of this fact without appeal to the continuum hypothesis.

Theorem. The space $X$ is homeomorphic to a subset of $\beta N-N$.

Proof. We first show that there is a compact separable space $S$ in which $X$ is embedded. This can be seen in at least two distinct ways. By a theorem in [2, p. 174] we can regard $X$ as a subset of $\mathscr{C}\left(H^{\infty}\right)$, the space of maximal ideals of $H^{\infty}$. (For a definition of $H^{\infty}$, the reader should consult [2]). According to the "Corona" conjecture proved by Carleson, the open unit disc is dense in $\mathscr{C}\left(H^{\infty}\right)$, and thus, $\mathscr{C l}\left(H^{\infty}\right)$ is a separable space. Thus, we may take $S=\mathscr{C}\left(H^{\infty}\right)$. An alternative, and more elementary, way is to notice that $L^{\infty}=C(X)$, a fact proved in $[2$, p. 170$]$, and hence that $C(X)$ has cardinality $C=$ $2^{\mathrm{N}^{0}}$; but this clearly implies that we can embed $X$ in the compact "cube" $[0,1]$, which according to $[4,3 N]$ is separable. Thus, we may take $S=[0,1]^{\mathrm{C}}$.

In any case, let $\varphi: N \rightarrow S$ be any mapping onto a dense subset of $S$. The Stone-Cech extension of $\varphi$, denoted by $\bar{\varphi}$, provides a mapping of $\beta N$ onto $S$. As it is well-known, using Zorn's lemma, we can find a closed subset $A$ of $\bar{\phi}^{-1}(X)$ such that $\bar{\phi}: A \rightarrow X$ is irreducible, i.e. $\bar{\varphi}$ is onto, and $\bar{\varphi}(B) \neq X$ for every proper closed subset $B$ of $A$. Gleason's lemma $[1,2.3]$, which applies since $X$ is extremally disconnected, states that $\bar{\varphi}$ is a homeomorphism. We can embed $\beta N$ into $\beta N-N$, and hence, the theorem is proved. 
2. Remarks. (i) The initial attempt to prove the above theorem, which failed, was the following: Let $S^{1}$ be the unit circle in the plane, and let $\sigma: X \rightarrow S^{1}$ be the natural projection (as described in [2, p.171]). A quick proof of the theorem would follow, if it could be shown that $\sigma$ were irreducible; but this is not the case.

(ii) The space $X$ is the only example known to the author of an extremally disconnected subspace of $\beta N$ which is not separable. Surely $X$ is not a retract of $\beta N$. It follows that although the projective objects (in the category of compact spaces and continuous maps) are "the retracts of the free objects" (in the terminology of Rainwater [5]), it is not true that a projective object is a retract of every free object in which it is embedded.

\section{REFERENCES}

1. A. Gleason, Projective topological spaces, Illinois J. Math. 2 (1958), 482-489.

2. K. Hoffman, Banach spaces of analytic functions, Prentice-Hall, Englewood Cliffs, 1962.

3. K. Hoffman and A. Ramsay, Algebras of bounded sequences, Pacific J. Math. 15 (1965), 1239-1248.

4. J. Kelley, General Topology, Van Nostrand, New York, 1950.

5. J. Rainwater, A note on projective resolutions, Proc. Amer. Math. Soc. 10 (1959), 734-735.

Received April 5, 1966.

INDIANA UNIVERSITY

AND

McGill University 


\section{PACIFIC JOURNAL OF MATHEMATICS}

\section{EDITORS}

\author{
H. SAMELSON \\ Stanford University \\ Stanford, California \\ J. P. JANS \\ University of Washington \\ Seattle, Washington 98105
}

\section{J. DugundJI}

University of Southern California Los Angeles, California 90007

RICHARD ARENS

University of California

Los Angeles, California 90024

\section{ASSOCIATE EDITORS}
E. F. BECKENBACH
B. H. NeumanN
F. WOLF
K. YOSIDA

\section{SUPPORTING INSTITUTIONS}

\author{
UNIVERSITY OF BRITISH COLUMBIA \\ CALIFORNIA INSTITUTE OF TECHNOLOGY \\ UNIVERSITY OF CALIFORNIA \\ MONTANA STATE UNIVERSITY \\ UNIVERSITY OF NEVADA \\ NEW MEXICO STATE UNIVERSITY \\ OREGON STATE UNIVERSITY \\ UNIVERSITY OF OREGON \\ OSAKA UNIVERSITY \\ UNIVERSITY OF SOUTHERN CALIFORNIA
}

\author{
STANFORD UNIVERSITY \\ UNIVERSITY OF TOKYO \\ UNIVERSITY OF UTAH \\ WASHINGTON STATE UNIVERSITY \\ UNIVERSITY OF WASHINGTON \\ AMERICAN MATHEMATICAL SOCIETY \\ CHEVRON RESEARCH CORPORATION \\ TRW SYSTEMS \\ NAVAL ORDNANCE TEST STATION
}

Mathematical papers intended for publication in the Pacific Journal of Mathematics should be typewritten (double spaced). The first paragraph or two must be capable of being used separately as a synopsis of the entire paper. It should not contain references to the bibliography. Manuscripts may be sent to any one of the four editors. All other communications to the editors should be addressed to the managing editor, Richard Arens at the University of California, Los Angeles, California 90024 .

50 reprints per author of each article are furnished free of charge; additional copies may be obtained at cost in multiples of 50 .

The Pacific Journal of Mathematics is published monthly. Effective with Volume 16 the price per volume (3 numbers) is $\$ 8.00$; single issues, $\$ 3.00$. Special price for current issues to individual faculty members of supporting institutions and to individual members of the American Mathematical Society: $\$ 4.00$ per volume; single issues $\$ 1.50$. Back numbers are available.

Subscriptions, orders for back numbers, and changes of address should be sent to Pacific Journal of Mathematics, 103 Highland Boulevard, Berkeley 8, California.

Printed at Kokusai Bunken Insatsusha (International Academic Printing Co., Ltd.), No. 6, 2-chome, Fujimi-cho, Chiyoda-ku, Tokyo, Japan.

PUBLISHED BY PACIFIC JOURNAL OF MATHEMATICS, A NON-PROFIT CORPORATION

The Supporting Institutions listed above contribute to the cost of publication of this Journal, but they are not owners or publishers and have no responsibility for its content or policies. 


\section{Pacific Journal of Mathematics \\ Vol. 20, No. $2 \quad$ October, 1967}

Edward Dewey Davis, Ideals of the principal class, $R$-sequences and a certain monoidal transformation ............................. 197

Richard Mansfield Dudley, Sub-stationary processes ................ 207

Newton Seymour Hawley and M. Schiffer, Riemann surfaces which are doubles of plane domains ......................... 217

Barry E. Johnson, Continuity of transformations which leave invariant certain translation invariant subspaces ................... 223

John Eldon Mack and Donald Glen Johnson, The Dedekind completion of

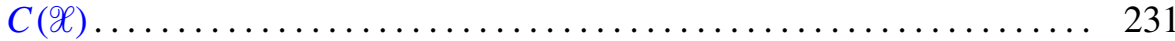

K. K. Mathur and R. B. Saxena, On the convergence of quasi-Hermite-Fejér interpolation................................... 245

H. D. Miller, Generalization of a theorem of Marcinkiewicz............ 261

Joseph Baruch Muskat, Reciprocity and Jacobi sums ............... 275

Stelios A. Negrepontis, On a theorem by Hoffman and Ramsay .......... 281

Paul Adrian Nickel, A note on principal functions and multiply-valent canonical mappings .............................. 283

Robert Charles Thompson, On a class of matrix equations ............. 289

David Morris Topping, Asymptoticity and semimodularity in projection lattices ........................................ 317

James Ramsey Webb, A Hellinger integral representation for bounded linear functionals

Joel John Westman, Locally trivial $C^{r}$ groupoids and their representations...

Hung-Hsi Wu, Holonomy groups of indefinite metrics 